\title{
General Theory of Inflammation: Patient Self-Administration of Hydrocortisone Safely Achieves Superior Control of Hydrocortisone- Responding Disorders by Matching Dosage with Symptom Intensity [Corrigendum]
}

Irwin JB, Baldwin AL, Stenberg VI. J Inflamm Res. 2019;12:161-166.

The authors have advised that there is an error in Table 2, the body mass of row two is shown in pounds rather than $\mathrm{kg}$.
Page 162, Table 2, Body mass column, second row, the text " 150 to $250 \mathrm{~kg}$ " should be "68 to $114 \mathrm{~kg}$ ".

The authors apologize for this error.

\section{Publish your work in this journal}

The Journal of Inflammation Research is an international, peerreviewed open-access journal that welcomes laboratory and clinical findings on the molecular basis, cell biology and pharmacology of inflammation including original research, reviews, symposium reports, hypothesis formation and commentaries on: acute/chronic inflammation; mediators of inflammation; cellular processes; molecular mechanisms; pharmacology and novel anti-inflammatory drugs; clinical conditions involving inflammation. The manuscript management system is completely online and includes a very quick and fair peerreview system. Visit http://www.dovepress.com/testimonials.php to read real quotes from published authors. 